\title{
Seasonal prevalence of pathogens and parasites in the savannah honeybee (Apis mellifera scutellata)
}

\author{
Ursula Strauss $^{1 *}$, Hannelie Human ${ }^{1}$, Laurent Gauthier ${ }^{2}$, Robin M. Crewe ${ }^{1}$, Vincent Dietemann ${ }^{1,2}$, \\ Christian W.W. Pirk ${ }^{1}$
}

${ }^{1}$ Social Insect Research Group, Department of Zoology and Entomology, University of Pretoria, Pretoria 0002, South Africa.

${ }^{2}$ Swiss Bee Research Centre, Agroscope Liebefeld-Posieux Research Station ALP, 3003 Bern, Switzerland.

Keywords: Apis mellifera scutellata; Varroa destructor; pathogen; virus; honeybee; parasite.

\author{
*Corresponding author: ustrauss@zoology.up.ac.za \\ Fax: (+27) 0123625242 \\ Tel: (+27) 0124202533 \\ Postal Address: Social Insect Research Group, Department of Zoology and Entomology, University of \\ Pretoria, Pretoria 0002, South Africa.
}

The loss of Apis mellifera L. colonies in recent years has, in many regions of the world, been alarmingly high. No single cause has been identified for these losses, but the interactions between several factors (mostly pathogens and parasites) have been held responsible. Work in the Americas on honeybees originating mainly from South Africa indicates that Africanized honeybees are less affected by the interplay of pathogens and parasites. However, little is known about the health status of South African honeybees (A. m. scutellata and A. m. capensis) in relation to pathogens and parasites. We therefore compared the seasonal prevalence of honeybee pathogens (viruses, bacteria, fungi) and parasites (mites, bee lice, wax moth, small hive beetles, A. m. capensis social parasites) between sedentary and migratory A. m. scutellata apiaries situated in the Gauteng region of South Africa. No significant differences were found in the prevalence of pathogens and parasites between sedentary and migratory apiaries. Three (Black queen cell virus, Varroa destructor virus 1 and Israeli acute paralysis virus) of the eight viruses screened were detected, a remarkable difference compared to European honeybees. Even though no bacterial pathogens were detected, Nosema apis and Chalkbrood were confirmed. All of the honeybee parasites were found in the majority of the apiaries with the most common parasite being the Varroa mite. In spite of hosting few pathogens, yet most parasites, A. $m$. scutellata colonies appeared to be healthy. 


\section{Introduction}

Honeybees (Apis mellifera L.) are valuable insects, known for their importance as pollinators and honey producers (Camazine and Morse, 1988; Morse and Calderone, 2000). The health of honeybees has been one of the most important topics in apicultural research in recent years (Genersch, 2010). This is primarily due to the recent emergence of high honeybee colony losses in many parts of the world (Le Conte et al., 2010; Neumann and Carreck, 2010; Stokstad, 2007; vanEngelsdorp et al., 2008) and the vulnerability of honeybees to parasitic mites, fungi, viruses and bacteria (Bailey and Ball, 1991; Chen et al., 2006; Dietemann et al., 2012; Genersch, 2010; Genersch et al., 2010; Martin, 2001; Ribière et al., 2010; Sammataro et al., 2000). These pathogens and parasites can have harmful effects on honeybee health and the services they offer, which in turn can lead to severe economic losses (Genersch, 2010; Morse and Calderone, 2000; Shen et al., 2005).

The majority of pathogens and parasites affecting honeybees have an almost worldwide distribution (Allen and Ball, 1996; Bailey and Ball, 1991; Ellis and Munn, 2005). However, the health status of honeybees in Africa is poorly characterized (Hepburn and Radloff, 1998; Dietemann et al., 2009). African honeybees are genetically diverse, with an estimated 310 million colonies in Africa and 10 million colonies in South Africa (Dietemann et al., 2009). Only a small proportion ( 100,000 colonies) of the South African population with its two subspecies (A. m. scutellata (Savannah honeybee) and (A. m. capensis (Cape honeybee)) is managed by beekeepers (Pirk et al., In prep.), which distinguishes it from the situation in Europe and North America.

One of the major effects of beekeeping on the health of the western honeybee has been the introduction of the ectoparasitic mite Varroa destructor (Rosenkranz et al, 2010; Dietemann et al., 2012). This parasite invaded the Western Cape region of South Africa approximately 15 years ago (Allsopp, 1997; Martin and Kryger, 2002). The mites spread quite rapidly to most parts of the country where they infested both wild and commercially kept honeybee colonies of both subspecies (Allsopp, 2006; Martin and Kryger, 2002). There were some reports of colony losses just after the initial invasion of Varroa mites into South Africa (Allsopp, 2006) as well as in Varroa mite infested colonies that tested positive for 
Black queen cell virus, Acute bee paralysis virus and two unnamed viruses (Davison et al., 1999; Swart et al., 2001). In contrast to many counties around the world, South Africa has not yet experienced the devastating effects of the ectoparasitic mite Varroa destructor and honeybee pathogens (Allsopp, 2006; Neumann and Carreck, 2010), despite average losses of between 20\% and 29\% in the years 2009-2011 (Pirk et al., In prep.). This might be due to a lack of continuous surveys investigating pathogen presence (Allen and Ball, 1996; Allsopp, 2006; Buys, 1982; Davison et al., 1999; Ellis and Munn, 2005; Hepburn and Radloff, 1998) or as a result of honeybees that are able to withstand the negative effects of these pathogens (Dietemann et al., 2009, Human et al., 2011).

In order to gain better insight into the health of A. m. scutellata, we screened colonies from 13 apiaries situated in the Gauteng region of South Africa for viruses, bacteria, fungi, bee lice, wax moth, small hive beetles, Varroa mites and capensis social parasites. Given the important role of viruses transmitted by Varroa mites (Allen and Ball, 1996; Bailey and Ball, 1991; Ball and Allen, 1988; BowenWalker et al., 1999; Chen and Siede, 2007; Ribière et al., 2008; Shen et al., 2005) in colony health, we also screened for their occurrence in the mites. Pathogen and parasite prevalence was compared between the colonies in sedentary and migratory apiaries in order to assess whether the movement of colonies for pollination purposes increases their susceptibility to pathogens and parasites.

\section{Materials and Methods}

\subsection{Sample collection}

Apparently healthy honeybee (Apis mellifera scutellata) colonies from 13 apiaries belonging to eight beekeepers were randomly selected and sampled each season from July 2010 to August 2011 (Fig 1, Table 1). Sampled apiaries were situated in and around the Gauteng region of South Africa. Sedentary apiaries $(n=5)$ remained at these locations permanently, while migratory apiaries $(n=8)$ were transported to other regions of South Africa (including the North West, Mpumalanga and Limpopo provinces) for pollination services before and between sampling occasions. All colonies were marked to ensure correct identification. Lost, dead or absconded colonies were replaced with new colonies (if 
available) in order to allow for continued monitoring of the selected apiaries. Two to five honeybee colonies were sampled per apiary (Table 1). On average, $202 \pm 103$ adult worker honeybees and 100 sealed worker brood cells were examined from each colony for the identification of pathogens and parasites. All samples were kept in a freezer $\left(-20^{\circ} \mathrm{C}\right)$ until analysed.

\subsection{Pathogen diagnosis}

The following honeybee pathogens were screened using PCR methods: Deformed wing virus (DWV), Black queen cell virus (BQCV), Varroa destructor virus 1 (VDV-1), Israeli acute paralysis virus (IAPV), Acute bee paralysis virus (ABPV), Chronic bee paralysis virus (CBPV), Sacbrood virus (SBV), Varroa destructor Macula-like virus (VdMLV), Nosema apis, Nosema ceranae, American foulbrood (AFB) and European foulbrood (EFB). Both adult honeybees and Varroa mites were screened for viruses whereas only adult honeybees were screened for N. apis, N. ceranae, AFB and EFB. Even though AFB and EFB are brood diseases, adult honeybees were screened as they act as carriers of these pathogens (Belloy et al., 2007; Wilson, 1971).

\subsubsection{Sample preparation}

For PCR diagnosis, six honeybees were pooled per colony from each apiary. When available, up to 45 adult female Varroa mites (phoretic on adult honeybees or in the brood) were pooled per apiary. Honeybees and Varroa mites were homogenised separately in TN buffer $(0.4 \mathrm{M} \mathrm{NaCl}$, Tris $10 \mathrm{mM}$ : pH 7.5) $(0.2 \mathrm{ml}$ per honeybee and $200 \mu \mathrm{l}$ per mite). The samples were placed into Eppendorf tubes and centrifuged at $5000 \mathrm{x} \mathrm{g}$ for 10 minutes. Fifty microlitres of the supernatant of each sample were transferred into Eppendorf tubes for total RNA/DNA extraction.

\subsubsection{RNA/DNA extraction and primer design}

For DWV, BQCV, VDV-1, IAPV, ABPV, CBPV, SBV and VdMLV identification, total RNA was extracted from honeybees and Varroa mites using a Nucleospin RNA II kit (Macherey-Nagel) according to the manufacturer's protocols. cDNA synthesis was performed with the M-MLV Reverse Transcriptase 
enzyme (Invitrogen). For each sample, $9 \mu \mathrm{l}$ of total extracted RNA, $1 \mu \mathrm{l}$ of random primers $(500 \mu \mathrm{g} / \mathrm{ml})$ and $2 \mu \mathrm{dNTPs}(2.5 \mathrm{mM})$ were added and incubated at $65{ }^{\circ} \mathrm{C}$ for 5 minutes. This was followed by the addition of $4 \mu \mathrm{l}$ of $5 \mathrm{X}$ cDNA buffer, $1 \mu \mathrm{LTT}(0.1 \mathrm{M}), 1 \mu \mathrm{l}$ RNAse inhibitor, $1 \mu \mathrm{l}$ water and $1 \mu \mathrm{M}$-MLV RT with a final volume of $20 \mu \mathrm{l}$ for each sample. Samples were centrifuged and then incubated at $25^{\circ} \mathrm{C}$ for 10 minutes, $37{ }^{\circ} \mathrm{C}$ for 60 minutes and finally at $70{ }^{\circ} \mathrm{C}$ for 15 minutes to inactivate the enzyme. The cDNA was diluted with $180 \mu \mathrm{l}$ of water resulting in a final volume of $200 \mu \mathrm{l}$ per sample. For $N$. apis, $N$. ceranae, EFB and AFB, total DNA was extracted using a Genomic DNA from Tissue kit (MachereyNagel) according to the manufacturer's protocols.

In order to gain better insight into the general occurrence of pathogens in these apiaries, honeybee cDNA/DNA from all apiaries ( $22 \mu 1$ per apiary) was pooled into one Eppendorf tube and the same was done for Varroa mite cDNA. If a positive result was obtained, additional PCR analysis per apiary was done to determine the specific apiary/apiaries infected.

Primers for BQCV, VDV-1 (1), VDV-1 (2) IAPV, ABPV, CBPV, VdMLV, SBV, N. apis, N. ceranae, EFB and AFB were obtained from the literature (Supplementary material - Table I). Seven primers (DWV 1-7) were used to screen for DWV in the winter 2010 samples. Primers for DWV (3-5) were designed using Primer Express ${ }^{\circledR}$ software (Applied Biosystems) and primers for DWV (1, 2, 6 and 7) were obtained from the literature (Supplementary material - Table I). Since none of these primers gave positive results, only DWV (1), DWV (2) and DWV (7) were used to screen the samples from the remaining seasons. Also, it was not possible to screen the winter 2010 pooled Varroa mite sample with DWV (2), DWV (7) and VDV-1 (2).

\subsubsection{PCR analyses}

Qualitative PCR was done to screen for DWV, BQCV, VDV-1, IAPV, ABPV, CBPV, VdMLV, $\mathrm{SBV}, N$. apis and $N$. ceranae across all seasons. In addition, honeybee samples collected from spring 2010-winter 2011 were screened for AFB and EFB using qualitative PCR. For PCR the following master 
mix was added: $5 \mu \mathrm{l}$ of cDNA/DNA, $4 \mu \mathrm{l}$ dNTPs $(2.5 \mathrm{mM}), 5 \mu \mathrm{l}$ of $10 \mathrm{X}$ reaction buffer, $1 \mu \mathrm{l}$ each of the forward and reverse primers $(10 \mu \mathrm{M}), 1.5 \mu 1 \mathrm{MgCl}_{2}(25 \mathrm{mM}), 32.3 \mu \mathrm{l}$ water and $0.2 \mu \mathrm{l}$ Platinum Taq polymerase (Invitrogen). The final volume of each sample was $50 \mu$ l. Positive (previously identified infected samples) and negative (water) controls were also included in all the PCR reactions. The PCR cycling conditions were set at $94{ }^{\circ} \mathrm{C}$ for 2 minutes, 35 cycles $\left(94{ }^{\circ} \mathrm{C}\right.$ for 30 seconds, $48-56{ }^{\circ} \mathrm{C}$ for $20-30$ seconds, $72{ }^{\circ} \mathrm{C}$ for 1 minute) and finally at $72{ }^{\circ} \mathrm{C}$ for 7 minutes (See Supplementary material - Table I for primer specific annealing temperatures of all screened pathogens). Each sample was loaded onto a $1.5 \%$ agarose gel stained with Goldview ${ }^{\circledR}$ and PCR products were visualised under UV light.

For AFB and EFB diagnosis, quantitative PCR was done for the winter 2010 samples only in a Rotor Gene following the program described in Roetschi et al., (2008). Samples were run for 2 minutes at 50 ${ }^{\circ} \mathrm{C}, 10$ minutes at $95{ }^{\circ} \mathrm{C}, 40$ cycles of 15 seconds at $95^{\circ} \mathrm{C}$ and finally for 1 minute at $60{ }^{\circ} \mathrm{C}$.

\subsubsection{Sequencing of amplified PCR products}

To confirm the accuracy of the diagnosis, a selected number of amplified PCR products of each pathogen were sequenced. PCR products were purified with a high pure PCR template preparation kit (Roche) according to the manufacturer's protocols. Obtained sequences were compared to entries in the NCBI database using the nucleotide BLAST program (http://blast.ncbi.nlm.nih.gov/Blast.cgi).

\subsection{Visual inspection for parasites and Chalkbrood}

Parasite and fungal pathogen presence were diagnosed by visual inspection of the adult honeybee and worker brood samples of each colony and included: V. destructor, bee lice (Braula coeca), A. m. capensis worker social parasites, small hive beetles (SHB) (Aethina tumida), wax moth (Galleria mellonella) and Chalkbrood (Ascosphaera apis). In this study, bee lice are grouped as parasites for convenience and comparison. Varroa mites and bee lice were separated simultaneously from adult honeybees using warm water (Allsopp, 2006). The presence of A. m. capensis social parasites was diagnosed based on the presence of multiple eggs in open brood cells, noticeably black honeybees and confirmation from beekeepers of capensis presence. SHB adults were identified in the adult honeybee 
samples whereas SHB larvae and eggs were identified in the sealed brood cells. The presence of wax moths was identified based on the occurrence of larvae and their excreta in sealed brood cells and on developing larvae/pupae/about to emerge honeybees. Chalkbrood was diagnosed using the presence of either white or black mummies in sealed and open worker brood cells.

\subsection{Statistical analysis}

A Chi-square test was performed to compare pathogen and parasite prevalence in migratory and sedentary honeybee colonies. Statistical analysis was performed with STATISTICA Version 10.

\section{Results}

The prevalence $(\%)$ of pathogens and parasites from both migratory and sedentary apiaries per season were pooled because of the absence of significant differences between the apiaries $(\mathrm{df}=1,0.01<$ $\left.\chi^{2}<3.61, P>0.05\right)$. A general overview of the presence of pathogens and parasites per season and per apiary is presented in Table 2 .

Bee lice were detected in 12 apiaries (92\%) and were highly prevalent in all seasons. Capensis social parasites were found in seven apiaries (54\%) across all seasons with low to intermediate prevalence. SHB were detected in nine apiaries (69\%) across all seasons. The prevalence of SHB was considerably higher in winter 2011 compared to winter 2010. Wax moths were very common in all seasons except winter 2011. Their presence was recorded in nine apiaries (69\%). White and black Chalkbrood mummies were found in six apiaries (46\%) across all seasons except winter 2011. Varroa mites were present in all 13 apiaries (100\%).

AFB, EFB and N. ceranae were not detected in the honeybee samples. Nosema apis was detected in winter 2010, spring 2010 and winter 2011 honeybee samples and its occurrence was limited to five apiaries (38\%). ABPV, CBPV, DWV, VdMLV and SBV were not detected in either honeybees or Varroa mites. Three apiaries $(23 \%)$ were virus free with the remaining eight apiaries having one or two viruses. BQCV was the most prevalent virus detected in honeybees. It was found in eight apiaries (62\%) and 
occurred across all seasons. It was highly prevalent in spring 2010, autumn 2011 and winter 2011 and less prevalent in summer 2010-2011. BQCV prevalence was noticeably lower in winter 2010 compared to winter 2011. BQCV was absent from all Varroa mite samples. IAPV was found in honeybees from two apiaries (15\%) only during spring 2010. IAPV was also detected in Varroa mites from one of these apiaries. VDV-1 presence was confirmed in honeybees from four apiaries (31\%) only during summer 2010-2011. Varroa mites from one of these apiaries also tested positive for VDV-1.

The co-occurrence of more than one pathogen and parasite per apiary was relatively common across all seasons (Table 2). During spring 2010, BQCV and IAPV were detected in two apiaries. Two more viruses (BQCV and VDV-1) were detected simultaneously in one apiary during summer 2010-2011. The simultaneous detection of BQCV and N. apis in honeybees was found in two apiaries. Overall, very few colony losses were reported. Beekeepers attributed most of the colony losses observed in this study to A. m. capensis social parasite infestation $(n=12)$. Damage by honey badgers $(n=1)$ and overall weakness of colonies due to unknown reasons $(n=1)$ were also recorded.

\section{Discussion}

A total of 10 pathogens and parasites were found in 13 honeybee apiaries in the Gauteng region of South Africa over a period of 14 months. No significant seasonal pattern relating to pathogen and parasite prevalence was observed (i.e. prevalence of many of the organisms was different in winter 2010 and 2011). We found a low prevalence of pathogens with no noticeable disease symptoms. The only exception was colonies infested with capensis social parasites which appeared weak and began to dwindle. Other honeybee parasites, including wax moth, bee lice and Varroa mites were found regularly across all seasons. Varroa mites were the most common parasites, but no negative effects, as reported in European honeybees (Rosenkranz et al., 2010) were observed. We also found IAPV, VDV-1, and BQCV, the latter being the most prevalent virus that occurred across all seasons.

By screening for various pathogens and parasites, we were able to assess the effect of two beekeeping management types on colony health. It has been suggested that the transportation of colonies 
for pollination or to follow nectar flow can negatively affect the health of honeybee colonies (Kryger et al., 2003; Ostiguy, 2010; Swart, 2001). Migratory colonies are also more likely to come into contact with other colonies, which increases the risk of pathogen transmission (Welch et al., 2009). In South Africa, $A$. m. capensis social parasites were more frequently encountered in migratory apiaries (Dietemann et al., 2006; Swart et al., 2001), most likely being transmitted through the close proximity of potential new hosts during migration (Kryger et al., 2003). In this study, however, honeybee pathogens and parasites were equally prevalent in both management types, with no significant differences found. This suggests that pathogens and parasites were present in both management types irrespective of whether the colonies were moved for pollination purposes or remained stationary on a permanent basis. Indeed, even in the USA recent surveys done in relation to winter colony losses found that losses experienced by beekeepers were also similar for both management types thereby indicating that the movement of colonies did not necessarily lead to higher colony losses (vanEngelsdorp et al., 2008, 2010).

In South Africa, wax moth and SHB are believed to affect only weak honeybee colonies (Lundie, 1940; Swart et al., 2001) and bee lice are regarded as a commensal rather than a threat to honeybees (Hepburn, 1978). However, information on the risk bee lice pose to colonies is contradictory (Crane, 1990; Gidey et al., 2012; Zaitoun and Al-Ghzawi, 2008) and requires further investigation. Bee lice have previously been reported in many countries around the world (Ellis and Munn, 2005), but have recently become less common in countries where chemicals are used to treat Varroa mites. Therefore, the African continent might serve as a refuge for this species, because chemical treatments are generally not used to control Varroa mites in African honeybee colonies.

However, capensis social parasites are more detrimental in A. m. scutellata colonies, since they have the ability to successfully infiltrate colonies and have been responsible for the death of thousands of A. m. scutellata colonies in South Africa (Allsopp and Crewe, 1993; Moritz et al., 2008; Neumann and Moritz, 2002). Our results showed no significant difference in the infestation rates of A. m. capensis social parasites between migratory and sedentary apiaries. This is unexpected given that it was recently demonstrated that migratory apiaries were more vulnerable to A. m. capensis social parasite infestation 
(Dietemann et al., 2006). Swart et al. (2001) also reported that A. m. capensis social parasite infestation rates were generally higher in migratory A. $m$. scutellata apiaries compared to sedentary apiaries. Since horizontal transmission can occur over a substantial distance (Moritz et al., 2008; Neumann et al., 2001), the lack of significant differences could be due to the transmission of this parasite between migratory (from surrounding beekeepers not part of the study) and sedentary apiaries through close contact (Dietemann et al., 2006).

Nosema apis is considered to be a widespread pathogen of adult honeybees in South Africa (Buys, 1976). Swart (2003) conducted three surveys over a period of 18 months and detected N. apis infestation in eight regions of the country, with migratory colonies having slightly higher $N$. apis infestation rates than sedentary colonies. This trend was not confirmed by our results. In this study, Nosema ceranae was not detected in any of the adult honeybee samples collected and thus far Algeria remains the only country in Africa that has reported this pathogen (Higes et al., 2009). Further investigation of the prevalence of $N$. ceranae on the African continent is required since its occurrence would be expected based on biological and climatic grounds. European bee-eaters (Merops apiaster) that migrate from Europe to Africa and particularly South Africa (Swart et al., 2001) might function as a vector for the spread of $N$. ceranae spores via regurgitated food pellets (Higes et al., 2008; Valera et al., 2011). In addition, $N$. ceranae appears to be more prevalent in areas with higher temperatures compared to N. apis (Fries, 2010) and could therefore establish itself in African honeybee populations occurring under warm climates.

The most recent assessment on EFB prevalence in eight regions of South Africa showed that $87 \%$ of the screened apiaries tested positive for EFB (Davison et al., 1999). In this study one honeybee sample tested positive for EFB, but this could not be confirmed with sequencing and consequently was not included as a positive result. AFB, which was only recently found in the Western Cape region of South Africa (Baxter, 2009; Human et al., 2011; OIE Report, 2009), was not detected in the apiaries sampled in this study. The non-detection of AFB in the samples does confirm, at least for the apiaries screened in this study, that this bacterial disease is still absent from some areas in the Gauteng region. 
During the initial spread of Varroa mites in South African honeybee colonies, the prevalence of Chalkbrood was found to be unusually higher than normal (Allsopp, 2004, 2006; Swart et al., 2001). Liu (1996) detected an increased occurrence of Chalkbrood in Varroa mite infested colonies compared to colonies that were free of the parasite and Medina and Mejia (1999) found that colonies in Mexico collapsed with a much lower number of Varroa mites when Chalkbrood was also present. In this study, Chalkbrood was detected in almost half of the apiaries screened. It is difficult to suggest a possible association between increased Chalkbrood presence and Varroa mites in this case because only a small piece of worker brood was used to identify Chalkbrood and a whole colony assessment for Chalkbrood was not done. Varroa mites were extremely prevalent in all 13 apiaries and across all seasons. Our results together with data from Allsopp (2006) confirm that Varroa mites are extremely common in South African honeybee colonies. On average for all apiaries per season, Varroa infestation rates were relatively low (despite the absence of chemical treatment) and never exceeded 4.0 mites per 100 adult honeybees (data not shown).

A total of eight viruses were screened in honeybees and Varroa mites. ABPV, CBPV, DWV, VdMLV and SBV were not detected in the honeybee or Varroa mite samples. With the exception of VdMLV, a recently discovered virus (Gauthier et al., 2011), all these viruses have previously been detected in South Africa (Allen and Ball, 1996; Davison et al., 1999). The non-detection of five of the eight viruses may indicate, that these viruses are either present at very low levels in the form of covert infections (Sumpter and Martin, 2004), or that they are simply not present in these apiaries. This corresponds to recent findings where honeybee (A. m. scutellata) samples from South Africa tested negative for three viruses (ABPV, IAPV and Kashmir bee virus) (Francis and Kryger, 2012), thereby confirming the low prevalence of viruses in A. m. scutellata.

Unexpectedly, only three viruses were detected, of which BQCV, IAPV and VDV-1 were found in honeybees during different periods of the year (Table 2). BQCV was present throughout the year and was the most prevalent virus detected. BQCV has previously been reported in South Africa (Allen and Ball, 1996; Davison et al., 1999; Leat et al., 2000) and more recently in Uganda (Kajobe et al., 2010). 
BQCV was also detected throughout the year in French apiaries (Tentcheva et al., 2004a). BQCV is closely associated with $N$. apis and the co-occurrence of these two pathogens can reduce the lifespan of infected adult honeybees (Allen and Ball, 1996; Bailey et al., 1983). In this study, a total of eight apiaries tested positive for BQCV of which two of these apiaries also tested positive for N. apis (25\% cooccurrence), thus only partly supporting an association between these pathogens. BQCV presence in honeybees only and not in Varroa mites is similar to results obtained in France (Tentcheva et al., 2004a) and Hungary (Forgach et al., 2008). Evidence from our and previous studies suggest that Varroa mites might not play a major role in transmitting this virus (Ball and Allen 1988; Carreck et al., 2002; Forgach et al., 2008; Locke et al., 2012; Ribière et al., 2008; Tentcheva et al., 2004a). However, BQCV was detected in Varroa mites from an apiary in Thailand (Chantawannakul et al., 2006) and it was found that Varroa mites can be vectors of BQCV (Ball, 1989; Johns, 2003). Consequently, more studies are required to clarify the relationship between $V$. destructor and BQCV (Chen and Siede, 2007).

IAPV was detected in honeybees and Varroa mites in our study. This virus was first diagnosed in Israel, where it reportedly caused large scale honeybee mortality and symptoms included trembling wings and paralysis (Maori et al., 2007; Palacios et al., 2008). The detection of IAPV in Varroa mites sampled during this study is therefore of concern, especially since it was recently confirmed that Varroa mites are capable of transmitting IAPV to honeybees (Di Prisco et al., 2011). However, IAPV was only recorded during spring 2010 in two apiaries, showing a low prevalence (Table 2).

We also detected VDV-1 in honeybees and mites. Its presence in mites is consistent with the fact that they function as host for the virus (Ongus, 2006). Zioni et al. (2011) suggested that this virus can cause deformed wings in honeybees, which we rarely observed in our study (pers. obs.). VDV-1 was only found in four apiaries during summer 2010-2011, once again illustrating a low prevalence in South Africa, whereas it appears to be quite prevalent in parts of Europe (Ongus, 2006) and was also found to be widespread in queens collected in France (Gauthier et al., 2011).

The absence of DWV from the honeybee and Varroa mite samples collected during this study was unexpected given its high prevalence in apiaries around the world (Allen and Ball, 1996; Baker and 
Schroeder, 2008; Berényi et al., 2006; Chen and Siede, 2007; Ellis and Munn, 2005; Martin et al., 1998; Tentcheva et al., 2004a) and the close association of DWV with Varroa mites (Bailey and Ball, 1991; Bowen-Walker et al., 1999; Dainat et al., 2012a; Gisder et al., 2009; Martin et al., 2012; Yang and CoxFoster, 2005; Yue and Genersch, 2005). Recently, DWV was also found to be absent from wild A. $\mathrm{m}$. scutellata drones collected in a South African Nature Reserve (Yañez et al., 2012) and honeybee samples from Uganda (Kajobe et al., 2010). The only record of DWV presence in South African honeybees was in 1993, prior to the arrival of Varroa mites (Allen and Ball, 1996). The rarity of DWV in South African or African honeybees, could explain the apparent health of these honeybee populations. Indeed, without the negative effect of this virus on their immune systems (Nazzi et al., 2012; Yang and Cox-Foster, 2005), African honeybees might be in a better position to withstand the negative effects of other pathogens and parasites. However, Africanized honeybees, that are genetically very similar to their African ancestors, (Kraus et al., 2007; Moritz et al., 2005; Schneider et al., 2004) are infected with DWV (Calderón et al., 2003; Ellis and Munn, 2005; Teixeira et al., 2008), but have not experienced large colony losses (Neumann and Carreck, 2010). This suggests that there might also be a genetic component that provides African and Africanized honeybees with a greater level of tolerance to pathogens and parasites, e.g. higher absconding rates, faster colony development rates, smaller colonies (Fletcher 1978; Hepburn and Radloff, 1998; Jaffé et al., 2009; Schneider et al., 2004).

Although our study covered only a small region of the country, our results are consistent with previously reported occurrences of pathogens and parasites. In addition, we report the first detection of IAPV and VDV-1 in South African honeybees as well as in Varroa mites infesting A. m. scutellata colonies. The most frequent cause of colony loss observed in this study was infestation by the capensis social parasite. The spread of this parasite is facilitated by beekeepers (Dietemann et al., 2006), but does not seem to affect wild populations (Härtel et al., 2006). The wild population therefore functions as a reservoir from which beekeepers refill their stocks and is therefore indirectly affected by this parasite (Dietemann et al., 2009). No colony losses in this study were directly attributed to Varroa mite presence or their associated pathogens. These results are in contrast to other studies around the world where Varroa 
mites played a significant or central role in colony losses (Bailey and Ball, 1991; Brodschneider et al., 2010; Dainat et al., 2012b; Dietemann et al., 2012; Guzman-Novoa et al., 2010; Ritter, 1981; Rosenkranz et al., 2010; Schäfer et al., 2010; Shimanuki et al., 1994). Also, the close association between Varroa mites and viruses (especially DWV, ABPV) and the subsequent colony losses they usually cause (Berthoud et al., 2010; Dainat et al., 2012a; Martin et al., 2012) were not observed in this study. Even though some apiaries in this study were occasionally infested with multiple pathogens and parasites, no obvious signs of disease were observed; thereby suggesting that the savannah honeybee population studied is resistant to these assaults.

\section{Acknowledgements}

We thank all the participating beekeepers for allowing us to collect samples from their apiaries, The National Research Foundation (PhD Fellowship/Incentive funding) and University of Pretoria (Glue funding) that provided funding. We are grateful to an anonymous reviewer for constructive comments on the manuscript.

\section{References}

Allen, M.F., Ball, B.V., 1996. The incidence and world distribution of the honey bee viruses. Bee World $77,141-162$.

Allsopp, M., 1997. Varroa jacobsoni in South Africa. S. Afr. Bee J. 69, 73-82.

Allsopp, M., 2004. Cape honeybee (Apis mellifera capensis Eshscholtz) and Varroa mite (Varroa destructor Anderson \& Trueman) threats to honeybees and beekeeping in Africa. Int. J. Trop. Insect Sci. 24, 87-94.

Allsopp, M., 2006. Analysis of Varroa destructor infestation of southern African honeybee populations. MSc-thesis, University of Pretoria, Pretoria, South Africa.

Allsopp, M., Crewe, R.M., 1993. The Cape honeybee as a Trojan horse rather than the hordes of Jenghiz Khan. Am. Bee J. 133, 121-123. 
Bailey, L., Ball, B.V., 1991. Honey Bee Pathology, Academic Press, London.

Bailey, L., Ball, B.V., Perry, J.N., 1983. Association of viruses with two protozoan pathogens of the honey bee. Ann. Appl. Biol. 103, 13-20.

Baker, A., Schroeder, D., 2008. Occurrence and genetic analysis of picorna-like viruses infecting worker bees of Apis mellifera L. populations in Devon, South West England. J. Invertebr. Pathol. 98, 239-242.

Bakonyi, T., Derakhshifar, I., Grabensteiner, E., Nowotny, N., 2003. Development and evaluation of PCR assays for the detection of Paenibacillus larvae in honey samples: Comparison with isolation and biochemical characterization. Appl. Environ. Microbiol. 69, 1504-1510.

Ball, B.V., 1989. Varroa jacobsoni as a virus vector, in: Cavalloro, R., (Ed.), Present status of Varroatosis in Europe and progress in the Varroa mite control. Proceedings of a meeting of the EC expert group, Luxembourg, pp. 241-244.

Ball, B.V., Allen, M.F., 1988. The prevalence of pathogens in honey bee (Apis mellifera) colonies infested with the parasitic mite Varroa jacobsoni. Ann. Appl. Biol. 113, 237-244.

Baxter, A., 2009. American foulbrood (AFB) in the Western Cape: advisory notice. S. Afr. Bee J. 81, 8-9.

Belloy, L., Imdorf, A., Fries, I., Forsgren, E., Berthoud, H., Kuhn, R., Charrière, J.D., 2007. Spatial distribution of Melissococcus plutonius in adult honeybees collected from apiaries and colonies with and without symptoms of European foulbrood. Apidologie 38, 136-140.

Berényi, O., Bakonyi, T., Derakhshifar, I., Koglberger, H., Nowotny, N., 2006. Occurrence of six honeybee viruses in diseased Austrian apiaries. Appl. Environ. Microbiol. 72, 2414-2420.

Berthoud, H., Imdorf, A., Haueter, M., Radloff, S., Neumann, P., 2010. Virus infections and winter losses of honey bee colonies (Apis mellifera). J. Apic. Res. 49, 60-65. 
Blanchard, P., Schurr, F., Olivier, V., Celle, O., Antunez, K., Bakonyi, T., Berthoud, H., Haubruge, E., Higes, M., Kasprzak, S., Koelberger, H., Kryger, P., Thiery, R., Ribière, M., 2009. Phylogenetic analysis of the RNA-dependant RNA polymerase (RdRp) and a predicted structural protein (pSP) of the chronic bee paralysis virus (CBPV) isolated from various geographical regions. Virus Res. $144,334-338$.

Bowen-Walker, P.L., Martin, S.J., Gunn, A., 1999. The transmission of deformed wing virus between honey bees (Apis mellifera L.) by the ectoparasitic mite Varroa jacobsoni Oud. J. Invertebr. Pathol. 73, 101-106.

Brodschneider, R., Moosbeckhofer, R., Crailsheim, K., 2010. Surveys as a tool to record winter losses of honey bee colonies: a two year case study in Austria and South Tyrol. J. Apic. Res. 49, 23-30.

Buys, B., 1976. Nosema incidence of honeybee on the Cape breeding station, in: Fletcher, D.J.C., (ed.), African Bees: Taxonomy, Biology and Economic use. Apimondia International Symposium, Pretoria, pp. 84-90.

Buys, B., 1982. A survey on honeybee pests in South Africa. S. Afr. Bee J. 54, 86-90.

Calderón, R.A., Van Veen, J., Arce, H.G., Esquivel, M.E., 2003. Presence of deformed wing virus and Kashmir bee virus in Africanized honey bee colonies in Costa Rica infested with Varroa destructor. Bee World 84, 112-116.

Camazine, S., Morse, R.A., 1988. The Africanized honeybee: The epithet "killer bee" is undeserved. Am. Sci. 76, 464-471.

Carreck, N.L., Ball, B.V., Wilson, J.K., 2002. Virus succession in honey bee colonies infested with Varroa destructor. Apiacta 37, 44-48.

Chantawannakul, P., Ward, L., Boonham, N., Brown, M., 2006. A scientific note on the detection of honeybee viruses using real-time PCR (TaqMan) in Varroa mites collected from a Thai honeybee (Apis mellifera) apiary. J. Invertebr. Pathol. 91, 69-73. 
Chen, Y.P., Evans, J.D., Smith, I.B., Pettis, J.S., 2008. Nosema ceranae is a long-present and widespread microsporidian infection of the European honey bee (Apis mellifera) in the United States. J. Invertebr. Pathol. 97, 186-188.

Chen, Y.P., Pettis, J.S., Collins, A., Feldlaufer, M.F., 2006. Prevalence and transmission of honeybee viruses. Appl. Environ. Microbiol. 72, 606-611.

Chen, Y.P., Siede, R., 2007. Honey bee viruses. Adv. Virus Res. 70, 33-80.

Crane, A., 1990. Bees and beekeeping, science, practice and world resources, Heinemann Professional Publishing Ltd, Halley Court, Jordan Hills, Oxford.

Dainat, B., Evans, J.D., Chen, Y.P., Gauthier, L., Neumann, P., 2012a. Dead or alive: Deformed wing virus and Varroa destructor reduce the life span of winter honeybees. Appl. Environ. Microbiol. $78,981-987$.

Dainat, B., Evans, J.D., Chen, Y.P., Gauthier, L., Neumann, P., 2012b. Predictive markers of honey bee colony collapse. PLoS ONE 7, e32151.

Davison, S., Govan, V., Leat, N., Allsopp, M., 1999. Bee diseases in South Africa 1: EFB, AFB, Chalkbrood and bee viruses. S. Afr. Bee J. 71, 84-87.

de Miranda, J.R., Fries, I., 2008. Venereal and vertical transmission of deformed wing virus in honeybees (Apis mellifera L.). J. Invertebr. Pathol. 98, 184-189.

Di Prisco, G., Pennacchio, F., Caprio, E., Boncristiani, H.F., Evans, J.D., Chen, Y.P., 2011. Varroa destructor is an effective vector of Israeli acute paralysis virus in the honeybee, Apis mellifera. J. Gen. Virol. 92, 151-155.

Dietemann, V., Lubbe, A., Crewe, R.M., 2006. Human factors facilitating the spread of a parasitic honey bee in South Africa. J. Econ. Entomol. 99, 7-13.

Dietemann, V., Pflugfelder, J., Anderson, D., Charrière, J.D., Chejanovsky, N., Dainat, B., de Miranda, J.R., Delaplane, K., Dillier, F.X., Fuchs, S., Gallmann, P., Gauthier, L., Imdorf, A., Koeniger, N., Kralj, J., Meikle, W., Pettis, J., Rosenkranz, P., Sammataro, D., Smith, D., Yañez, O., Neumann, P., 2012. Varroa destructor: research avenues towards sustainable control. J. Apic. Res. 51, 125- 
132.

Dietemann, V., Pirk, C.W.W., Crewe, R.M., 2009. Is there a need for conservation of honeybees in Africa? Apidologie 40, 285-295.

Ellis, J.D., Munn, P.A., 2005. The worldwide health status of honey bees. Bee World 86, 88-101.

Fletcher, D.J.C., 1978. The African bee, Apis mellifera adansonii, in Africa. Annu. Rev. Entomol. 23, 151-171.

Forgach, P., Bakonyi, T., Tapaszti, Z., Nowotny, N., Rusvai, M., 2008. Prevalence of pathogenic bee viruses in Hungarian apiaries: situation before joining the European Union. J. Invertebr. Pathol. 98, 235-238.

Forsgren, E., de Miranda, J.R., Isaksson, M., Wei, S., Fries, I., 2009. Deformed wing virus associated with Tropilaelaps mercedesae infesting European honey bees (Apis mellifera). Exp. Appl. Acarol. 47, 87-97.

Francis, R.M., Kryger, P., 2012. Single assay detection of Acute Bee Paralysis Virus, Kashmir Bee Virus and Israeli Acute Paralysis Virus. J. Apic. Sci. 56, 137-145.

Fries, I., 2010. Nosema ceranae in European honey bees (Apis melllifera). J. Invertebr. Pathol. 103, S73S79.

Gauthier, L., Ravallec, M., Tournaire, M., Cousserans, F., Bergoin, M., Dainat, B., de Miranda, J.R., 2011. Viruses associated with ovarian degeneration in Apis mellifera L. queens. PLoS ONE 6, e16217.

Gauthier, L., Tentcheva, D., Tournaire, M., Dainat, B., Cousserans, F., Colin, M.E., Bergoin, M., 2007. Viral load estimation in asymptomatic honey bee colonies using the quantitative RT-PCR technique. Apidologie 38, 426-435.

Genersch, E., 2005. Development of a rapid and sensitive RT-PCR method for the detection of Deformed wing virus, a pathogen of the honeybee (Apis mellifera). Vet. J. 169, 121-123.

Genersch, E., 2010. Honey bee pathology: current threats to honey bees and beekeeping. Appl. Microbiol. Biotechnol. 87, 87-97. 
Genersch, E., Von Der Ohe, W., Kaatz, H., Schroeder, A., Otten, C., Büchler, R., Berg, S., Ritter, W., Muhlen, W., Gisder, S., Meixner, M., Liebig, G., Rosenkranz, P., 2010. The German bee monitoring project: a long term study to understand periodically high winter losses of honey bee colonies. Apidologie 41, 332-352.

Gidey, A., Mulugeta, S., Fromsa, A., 2012. Prevalence of bee lice Braula coeca (Diptera: Braulidae) and other perceived constraints to honey bee production in Wukro Woreda, Tigray Region Ethiopia. Glob. Vet. 8, 631-635.

Gisder, S., Aumeier, P., Genersch, E., 2009. Deformed wing virus (DWV): viral load and replication in mites (Varroa destructor). J. Gen. Virol. 90, 463-467.

Guzman-Novoa, E., Eccles, L., Calvete, Y., McGowan, J., Kelly, P.G., Correa-Benitez, A., 2010. Varroa destructor is the main culprit for the death and reduced populations of overwintered honey bee (Apis mellifera) colonies in Ontario, Canada. Apidologie 41, 443-450.

Härtel, S., Neumann, P., Kryger, P., von der Heide, C., Moltzer, G.J., Crewe, R.M., van Praagh, J.P., Moritz, R.F.A., 2006. Infestation levels of Apis mellifera scutellata swarms by socially parasitic Cape honeybee workers (Apis mellifera capensis). Apidologie 37, 462-470.

Hepburn, H.R., 1978. The bee louse. S. Afr. Bee J. 50, 11-12.

Hepburn, H.R., Radloff, S.E., 1998. Honeybees of Africa. Springer, Berlin.

Higes, M., Martín-Hernández, R., Garrido-Bailon, E., Botias, C., Meana, A., 2009. The presence of Nosema ceranae (Microsporidia) in North African honey bees (Apis mellifera intermissa). J. Apic. Res. 48, 217-219.

Higes, M., Martín-Hernández, R., Garrido-Bailón, E., Botías, C., García-Palencia, P., Meana, A., 2008. Regurgitated pellets of Merops apiaster as fomites of infective Nosema ceranae (Microsporidia) spores. Environ. Microbiol. 5, 1374-1379.

Human, H., Pirk, C.W.W., Crewe, R.M., Dietemann, V., 2011. The honeybee disease American foulbrood - An African perspective. Afr. Entomol. 19, 551-557. 
Jaffé, R., Dietemann, V., Allsopp, M., Costa, C., Crewe, R.M., Dall’Olio, R., De La Rúa, P., ElNiweiri, M.A.A., Fries, I., Kezic, N., Meusel, M.S., Paxton, R.J., Shaibi, T., Stolle, E., Moritz, R.F.A., 2009. Estimating the density of honey bee colonies across their natural range to fill the gap in pollinator decline censuses. Conserv. Biol. 24, 583-593.

Johns, J., 2003. Investigation into South African honey bee viruses and their association with the parasitic mite Varroa destructor (Acarini: Varroidae). MSc thesis, University of the Western Cape, Cape Town, South Africa.

Kajobe, R., Marris, G., Budge, G., Laurenson, L., Cordoni, G., Jones, B., Wilkins, S., Cuthbertson, A.G.S., Brown, M.A., 2010. First molecular detection of a viral pathogen in Ugandan honey bees. J. Invertebr. Pathol. 104, 153-156.

Kraus, F.B., Franck, P., Vandame, R., 2007. Asymmetric introgression of African genes in honeybee populations (Apis mellifera L.) in Central Mexico. Heredity 99, 233-240.

Kryger, P., Dietemann, V., Crewe, R.M., 2003. Have we found a solution to the Capensis problem? S. Afr. Bee J. 75, 123-128.

Leat, N., Ball, B., Govan, V., Davison, S., 2000. Analysis of the complete genome sequence of black queen-cell virus, a picorna-like virus of honey bees. J. Gen. Virol. 81, 2111-2119.

Le Conte, Y., Ellis, M., Ritter, W., 2010. Varroa mites and honey bee health: can Varroa explain part of the colony losses? Apidologie 41, 353-363.

Liu, T., 1996. Varroa mites as carriers of honey bee chalkbrood. Am. Bee J. 136, 655-655.

Locke, B., Forsgren, E., Fries, I., de Miranda, J.R., 2012. Acaricide treatment affects viral dynamics in Varroa destructor-infested honey bee colonies via both host physiology and mite control. Appl. Environ. Microbiol. 78, 227-235.

Lundie, A.E., 1940. The small hive beetle: Aethina tumida. Science Bulletin 220, Union of South Africa, Department of Agriculture and Forestry Entomological Series 3. 
Maori, E., Lavi, S., Mozes-Koch, R., Gantman, Y., Peretz, Y., Edelbaum, O., Tanne, E., Sela, I., 2007. Isolation and characterization of Israeli acute paralysis virus, a dicistrovirus affecting honeybees in Israel: evidence for diversity due to intra-and inter-species recombination. J. Gen. Virol. 88, $3428-3438$.

Martin, S.J., 2001. The role of Varroa and viral pathogens in the collapse of honeybee colonies: a modelling approach. J. Appl. Ecol. 38, 1082-1093.

Martin, S.J., Kryger, P., 2002. Reproduction of Varroa destructor in South African honey bees: does cell space influence Varroa male survivorship? Apidologie 33, 51-61.

Martin, S.J., Highfield, A.C., Brettell, L., Villalobos, E.M., Budge, G.E., Powell, M., Nikaido, S., Schroeder, D.C., 2012. Global honey bee viral landscape altered by a parasitic mite. Science 336, 1304-1306.

Martin, S.J., Hogarth, A., Van Breda, J., Perrett, J., 1998. A scientific note on Varroa jacobsoni Oudemans and the collapse of Apis mellifera colonies in the United Kingdom. Apidologie 29, 369-370.

Medina, L.M., Mejia, E.V., 1999. The presence of Varroa jacobsoni mite and Ascosphaera apis fungi in collapsing and normal honey bee (Apis mellifera L.) colonies in Yucatan, Mexico. Am. Bee J. 139, 794-796.

Moritz, R.F.A., Härtel, S., Neumann, P., 2005. Global invasions of the western honey bee (Apis mellifera) and the consequences for biodiversity. Ecoscience 12, 289-301.

Moritz, R.F.A., Pirk, C.W.W., Hepburn, H.R., Neumann, P., 2008. Short-sighted evolution of virulence in parasitic honeybee workers (Apis mellifera capensis Esch.). Naturwissenschaften $95,507-513$.

Morse, R.A., Calderone, N.W., 2000. The value of honey bee pollination in the United States. Bee Culture 128, 1-15. 
Nazzi, F., Brown, S.P., Annoscia, D., Del Piccolo, F., Di Prisco, G., Varricchio, P., Della Vedova, G., Cattonaro, F., Caprio, E., Pennacchio, F., 2012. Synergistic parasite-pathogen interactions mediated by host immunity can drive the collapse of honeybee colonies. PLoS Pathogens 8 , e1002735.

Neumann, P., Carreck, N.L., 2010. Honey bee colony losses. J. Apic. Res. 49, 1-6.

Neumann, P., Moritz, R.F.A., 2002. The Cape honeybee phenomenon: the sympatric evolution of a social parasite in real time? Behav. Ecol. Sociobiol. 52, 271-281.

Neumann, P., Radloff, S.E., Moritz, R.F.A., Hepburn, H.R., Reece, S.L., 2001. Social parasitism by honeybee workers (Apis mellifera capensis Esch.): Host finding and resistance of hybrid host colonies. Behav. Ecol. 12, 419-428.

OIE Report., 2009. American foulbrood of honeybees, South Africa. http://www.oie.int/wahis_2/public. OIE Reference: 1092. (13-03-2013).

Ongus, J.R., 2006. Varroa destructor virus 1: A new picorna-like virus in Varroa mites as well as honey bees. PhD thesis, Wageningen University, The Netherlands.

Ongus, J.R., Peters, D., Bonmatin, J.M., Bengsch, E., Vlak, J.M., Van Oers, M.M., 2004. Complete sequence of a picorna-like virus of the genus Iflavirus replicating in the mite Varroa destructor. J. Gen. Virol. 85, 3747-3755.

Ostiguy, S., 2010. Sustainable beekeeping: managed pollinator CAP coordinated agricultural project - a national research and extension initiative to reverse pollinator decline. Am. Bee J. 150, 149-152.

Palacios, G., Hui, J., Quan, P.L., Kalkstein, A., Honkavuori, K.S., Bussetti, A.V., Conlan, S., Evans, J., Chen, Y.P., vanEngelsdorp, D., Efrat, H., Pettis, J., Cox-Foster, D., Holmes, E.C., Briese, T., Lipkin, W.I., 2008. Genetic analysis of Israel acute paralysis virus: distinct clusters are circulating in the United States. J. Virol. 82, 6209-6217.

Ribière, M., Ball, B.V., Aubert, M.F.A., 2008. Natural history and geographic distribution of honey bee viruses, in: Aubert, M.F.A., Ball, B.V., Fries, I., Milani, N., Moritz, R.F.A. (Eds.), Virology and the Honey Bee, VIth Framework, EC Publications, Brussels, pp. 15-84. 
Ribière, M., Triboulot, C., Mathieu, L., Aurieres, C., Faucon, J.P., Pepin, M., 2002. Molecular diagnosis of chronic bee paralysis virus infection. Apidologie 33, 339-351.

Ribière, M., Olivier, V., Blanchard, P., 2010. Chronic bee paralysis: A disease and a virus like no other? J. Invertebr. Pathol. 103, 120-131.

Ritter, W., 1981. Varroa disease of the honeybee Apis mellifera. Bee World 62, 141-153.

Roetschi, A., Berthoud, H., Kuhn, R., Imdorf, A., 2008. Infection rate based on quantitative real-time PCR of Melissococcus plutonius, the causal agent of European foulbrood, in honeybee colonies before and after apiary sanitation. Apidologie 39, 362-371.

Rosenkranz, P., Aumeier, P., Ziegelmann, B., 2010. Biology and control of Varroa destructor. J. Invertebr. Pathol. 103, 96-119.

Sammataro, D., Gerson, U., Needham, G., 2000. Parasitic mites of honey bees: life history, implications, and impact. Annu. Rev. Entomol. 45, 519-548.

Schäfer, M.O., Ritter, W., Pettis, J.S., Neumann, P., 2010. Winter losses of honeybee colonies (Hymenoptera: Apidae): the role of infestations with Aethina tumida (Coleoptera: Nitidulidae) and Varroa destructor (Parasitiformes: Varroidae). J. Econ. Entomol. 103, 10-16.

Schneider, S.S., DeGrandi-Hoffman, G., Smith, D.R., 2004. The African honey bee: factors contributing to a successful biological invasion. Annu. Rev. Entomol. 49, 351-376.

Shen, M., Cui, L., Ostiguy, N., Cox-Foster, D., 2005. Intricate transmission routes and interactions between picorna-like viruses (Kashmir bee virus and sacbrood virus) with the honeybee host and the parasitic varroa mite. J. Gen. Virol. 86, 2281-2289.

Shimanuki, H., Calderone, N.W., Knox, D.A., 1994. Parasitic mite syndrome: the symptoms. Am. Bee J. $134,827-828$.

Stokstad, E., 2007. The case of the empty hives. Science 316, 970-972.

Sumpter, D.J.T., Martin, S.J., 2004. The dynamics of virus epidemics in Varroa infested honey bee colonies. J. Anim. Ecol. 73, 51-63. 
Swart, D.J., 2001. Specialized management, in: Johannsmeier, M.F., (Ed.), Beekeeping in South Africa. Plant Protection Handbook No. 14, Agricultural Research Council, Pretoria, pp. 85-94.

Swart, D.J., 2003. The occurrence of Nosema apis (Zander), Acarapis woodi (Rennie), and the Cape problem bee in the summer rainfall region of South Africa. MSc thesis, Rhodes University, Grahamstown, South Africa.

Swart, D.J., Johannsmeier, M.R., Tribe, G.D., Kryger, P., 2001. Diseases and pests of honeybees, in: Johannsmeier, M.F., (Ed.), Beekeeping in South Africa. Plant Protection Handbook No. 14, Agricultural Research Council, Pretoria, pp. 198-222.

Teixeira, E.W., Chen, Y.P., Message, D., Pettis, J., Evans, J.D., 2008. Virus infections in Brazilian honey bees. J. Invertebr. Pathol. 99, 117-119.

Tentcheva, D., Gauthier, L., Zappulla, N., Dainat, B., Cousserans, F., Colin, M.E., Bergoin, M., 2004a. Prevalence and seasonal variations of six bee viruses in Apis mellifera L. and Varroa destructor mite populations in France. Appl. Environ. Microbiol. 70, 7185-7191.

Tentcheva, D., Gauthier, L., Jouve, S., Canabady-Rochelle, L., Dainat, B., Cousserans, F., Colin, M.E., Ball, B.V., Bergoin, M., 2004b. Polymerase chain reaction detection of deformed wing virus (DWV) in Apis mellifera L. and Varroa destructor. Apidologie 35, 431-439.

Valera, F., Martín-Hernández, R., Higes, M., 2011. Evaluation of large-scale dissemination of Nosema ceranae spores by European bee-eaters Merops apiaster. Environ. Microbiol. Reports 3, 47-53.

vanEngelsdorp, D., Hayes, J., Underwood, R.M., Pettis, J.S., 2008. A survey of honey bee colony losses in the U.S., fall 2007 to spring 2008. PLoS ONE 3, e4071.

vanEngelsdorp, D., Hayes, J., Underwood, R.M., Pettis, J.S., 2010. A survey of honey bee colony losses in the United States, fall 2008 to spring 2009. J. Apic. Res. 49, 7-14.

Welch, A., Drummond, F., Tewari, S., Averill, A., Burand, J.P., 2009. Presence and prevalence of viruses in local and migratory honeybees (Apis mellifera) in Massachusetts. Appl. Environ. Microbiol. $75,7862-7865$. 
Wilson, W.T., 1971. Resistance to American foulbrood in honey bees. XI. Fate of Bacillus larvae spores ingested by adults. J. Invertebr. Pathol. 17, 247-255.

Yañez, O., Jaffé, R., Jarosch, A., Fries, I., Moritz, R.F.A., Paxton, R.J., de Miranda, J.R., 2012. Deformed wing virus and drone mating flights in the honey bee (Apis mellifera): implications for sexual transmission of a major honey bee virus. Apidologie 43, 17-30.

Yang, X., Cox-Foster, D., 2005. Impact of an ectoparasite on the immunity and pathology of an invertebrate: evidence for host immunosuppression and viral amplification. Proc. Natl. Acad. Sci. U. S. A. $102,7470-7475$.

Yue, C., Genersch, E., 2005. RT-PCR analysis of Deformed wing virus in honeybees (Apis mellifera) and mites (Varroa destructor). J. Gen. Virol. 86, 3419-3424.

Zaitoun, S., Al-Ghzawi, A.A., 2008. Daily number of bee louse (Braula coeca) in honey bee (Apis mellifera carnica and A. m. syriaca) colonies maintained under semi-arid conditions. Insect Sci. $15,563-567$.

Zioni, N., Soroker, V., Chejanovsky, N., 2011. Replication of Varroa destructor virus 1 (VDV-1) and a Varroa destructor virus 1 - deformed wing virus recombinant (VDV-1-DWV) in the head of the honey bee. Virology 417, 106-112. 


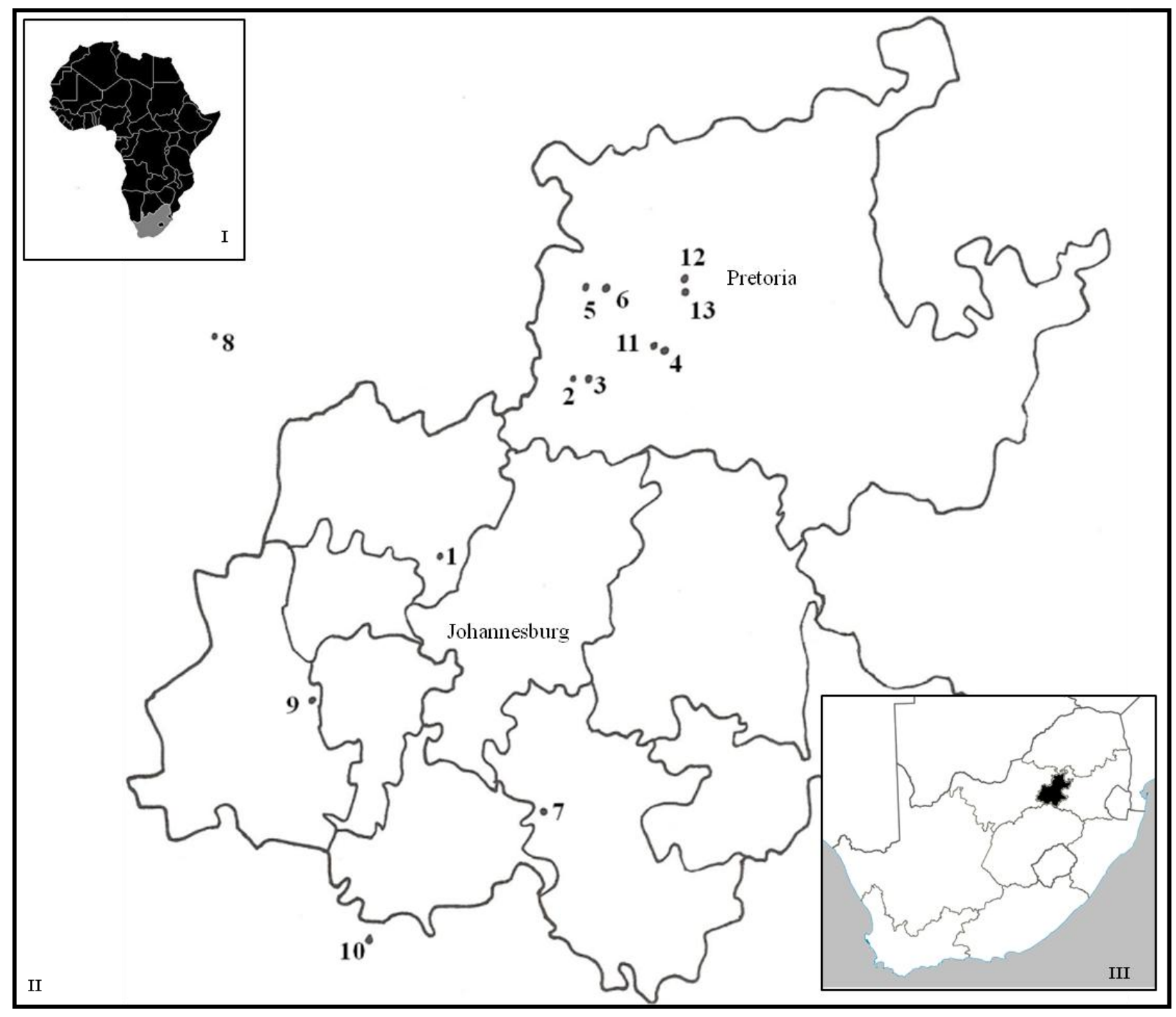

Figure 1. (I) Map of Africa with South Africa highlighted in grey. (II) Map of the Gauteng province of South Africa showing the localities from which samples were collected. Localities 8 and 10 are in the North West and Free State provinces, respectively. The remaining localities are situated in the Gauteng province. (III) Map showing the nine provinces of South Africa with Gauteng highlighted in black. (Maps I-III were adapted and modified from Wikipedia.org). 
Table 1. Sampling locations and number of honeybee colonies screened per season for the presence of pathogens and parasites.

\begin{tabular}{cllccccc}
\hline $\begin{array}{c}\text { Apiary } \\
\text { code }\end{array}$ & \multicolumn{1}{c}{ Locality } & $\begin{array}{c}\text { Management } \\
\text { type }\end{array}$ & $\begin{array}{c}\text { Winter } \\
(\text { Jul-Aug } \\
\mathbf{2 0 1 0}\end{array}$ & $\begin{array}{c}\text { Spring } \\
\text { (Sept-Nov } \\
\mathbf{2 0 1 0})\end{array}$ & $\begin{array}{c}\text { Summer } \\
\text { (Dec 2010- } \\
\text { Feb 2011) }\end{array}$ & $\begin{array}{c}\text { Autumn } \\
\text { (Mar-May } \\
\text { 2011) }\end{array}$ & $\begin{array}{c}\text { Winter } \\
\text { (Jun-Aug } \\
\text { 2011) }\end{array}$ \\
\hline & Krugersdorp & Sedentary & 5 & 5 & - & 5 & 5 \\
1 & Magaliesberg Site 1 & Migratory & 4 & 4 & 2 & 5 & 5 \\
2 & Magaliesberg Site 2 & Migratory & 5 & 5 & 5 & 5 & 5 \\
3 & Pretoria (Hatfield) & Sedentary & 5 & 5 & 5 & 5 & 5 \\
4 & Soshanguve Site 1 & Migratory & 5 & - & - & - & - \\
6 & Soshanguve Site 2 & Migratory & 5 & - & - & - & - \\
7 & Meyerton & Migratory & - & 5 & 5 & - & - \\
8 & Rustenburg & Sedentary & - & - & 5 & - & - \\
9 & Randfontein & Sedentary & - & - & 5 & - & - \\
10 & Parys & Migratory & - & - & 3 & - & - \\
11 & Pretoria (Brooklyn) & Sedentary & - & - & 5 & 5 & 5 \\
12 & Pretoria North Site 1 & Migratory & - & - & 5 & - & - \\
13 & Pretoria North Site 2 & Migratory & - & - & 5 & - & - \\
\hline
\end{tabular}


Table 2. Presence of pathogens and parasites per apiary during Winter 2010, Spring 2010, Summer 2010-2011, Autumn 2011 and Winter 2011.

\begin{tabular}{|c|c|c|c|c|c|c|c|c|c|c|c|}
\hline \multirow[b]{2}{*}{ Season } & \multirow[b]{2}{*}{$\begin{array}{l}\text { Apiary } \\
\text { code }\end{array}$} & \multicolumn{3}{|c|}{ Viruses } & \multicolumn{2}{|c|}{ Fungi } & \multicolumn{5}{|c|}{ Parasites } \\
\hline & & BQCV & VDV-1 & IAPV & $\begin{array}{c}\text { Nosema } \\
\text { apis }\end{array}$ & $\begin{array}{l}\text { Chalk- } \\
\text { brood }\end{array}$ & Varroa & A.m.c. & Braula & $\begin{array}{l}\text { Wax } \\
\text { moth }\end{array}$ & SHB \\
\hline \multirow{6}{*}{$\begin{array}{c}\text { Winter } \\
2010\end{array}$} & 1 & - & - & - & - & - & + & - & + & + & - \\
\hline & 2 & - & - & - & + & + & + & - & + & + & - \\
\hline & 3 & + & - & - & + & + & + & - & + & + & + \\
\hline & 4 & - & - & - & - & - & + & - & + & + & - \\
\hline & 5 & - & - & - & - & - & + & + & + & - & - \\
\hline & 6 & - & - & - & - & + & + & + & + & + & - \\
\hline \multirow{5}{*}{$\begin{array}{c}\text { Spring } \\
2010\end{array}$} & 1 & - & - & - & - & - & + & - & + & + & - \\
\hline & 2 & + & - & $+/+$ & - & + & + & - & + & - & - \\
\hline & 3 & + & - & - & - & + & + & - & + & - & - \\
\hline & 4 & + & - & + & - & - & + & - & + & + & - \\
\hline & 7 & + & - & - & - & - & + & - & + & + & + \\
\hline
\end{tabular}




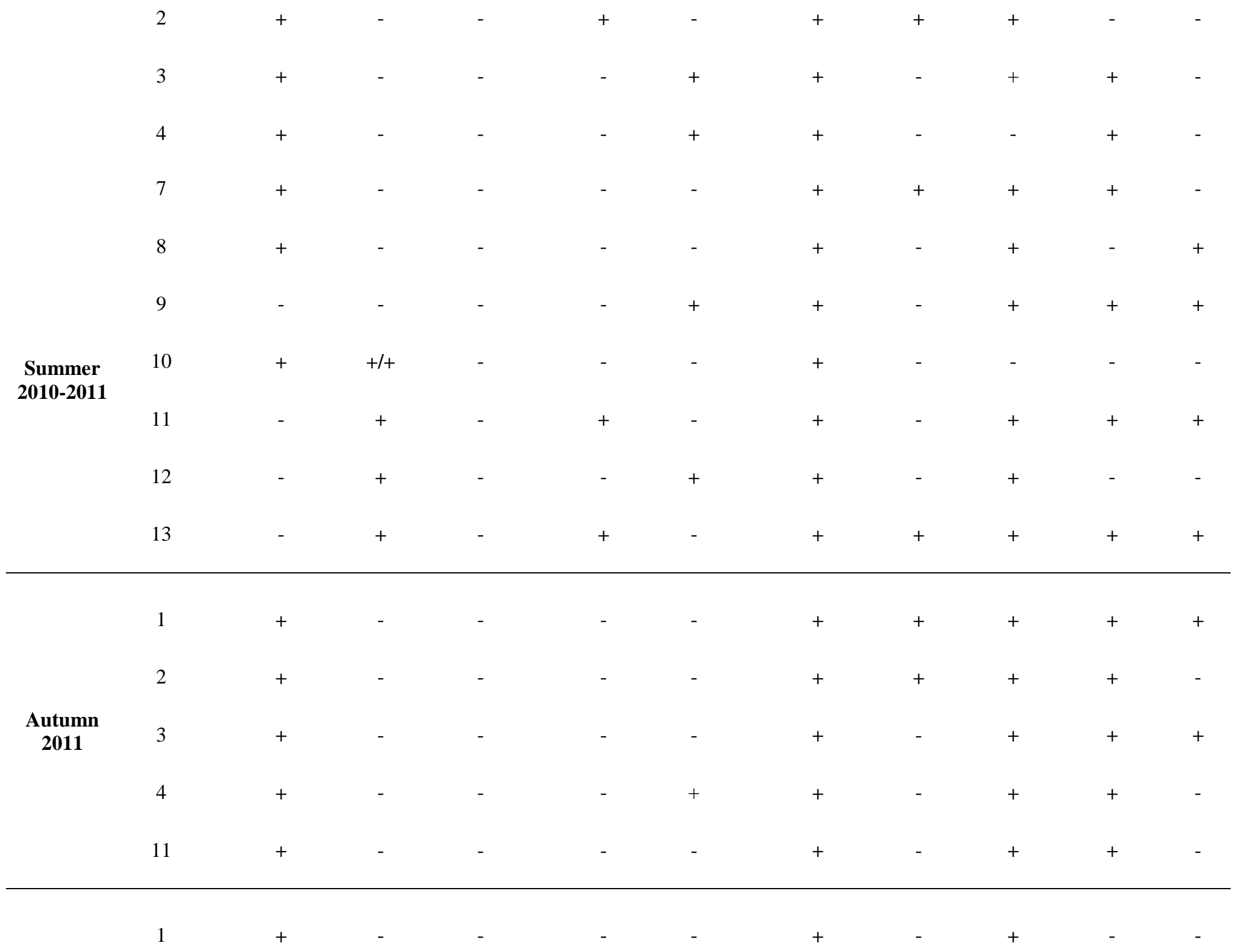




\begin{tabular}{|c|c|c|c|c|c|c|c|c|c|c|c|}
\hline & 2 & - & - & - & - & - & + & + & + & - & + \\
\hline \multirow[t]{3}{*}{$\begin{array}{c}\text { Winter } \\
2010\end{array}$} & 3 & + & - & - & - & - & + & - & + & - & + \\
\hline & 4 & + & - & - & + & - & + & + & + & + & + \\
\hline & 11 & + & - & - & - & - & + & - & + & - & + \\
\hline
\end{tabular}




\section{Supplementary Material}

Table I. Primers used for the screening of DWV, BQCV, VDV-1, IAPV, ABPV, CBPV, SBV, VdMLV, Nosema apis, Nosema ceranae, EFB and AFB.

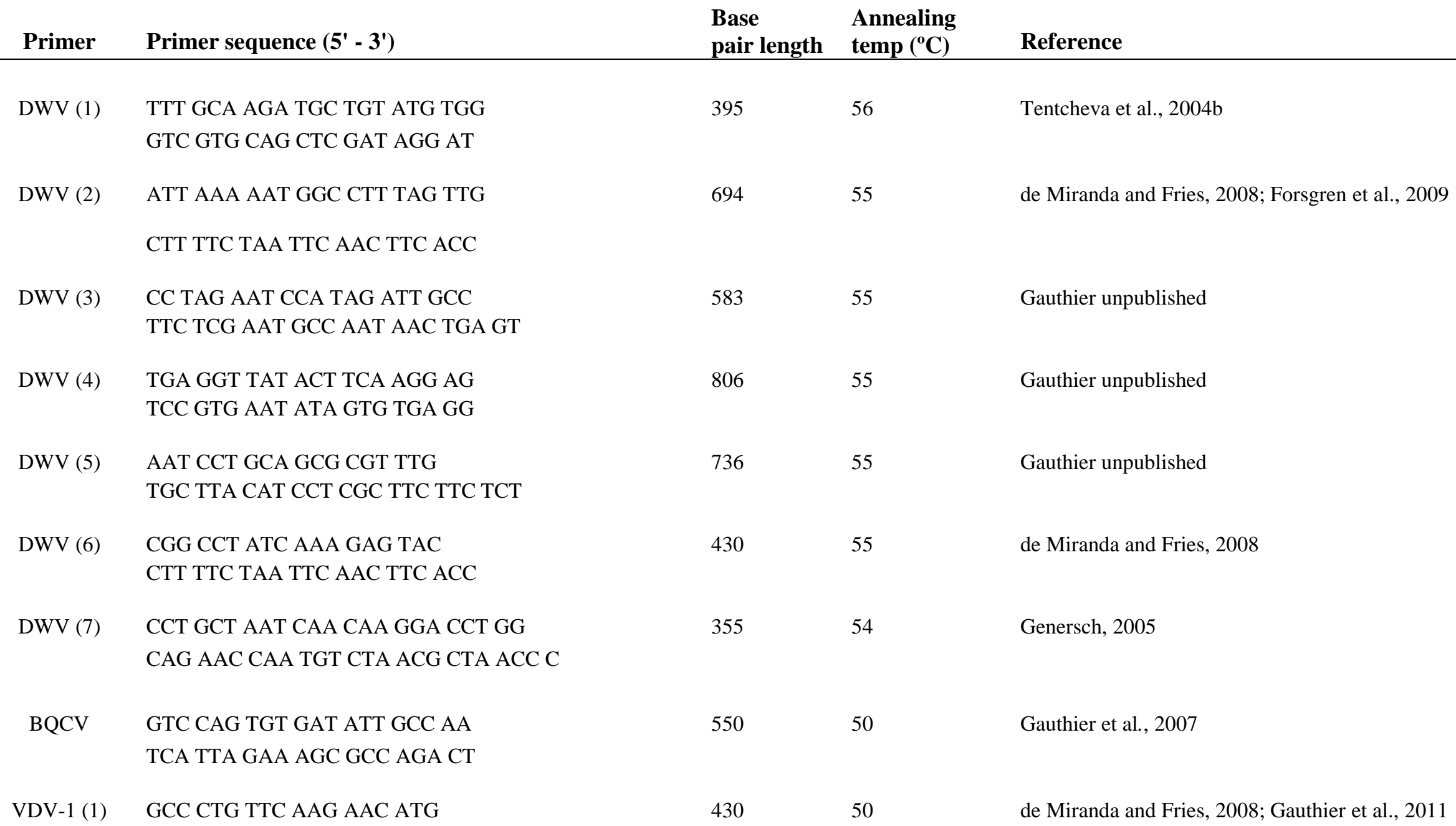




\begin{tabular}{|c|c|c|c|c|}
\hline VDV-1 (2) & $\begin{array}{l}\text { CGA AAC GAA GAG AGC ATG TAT } \\
\text { CGA CTC TTC CCC AGC TAA G }\end{array}$ & 1130 & 55 & Ongus et al., 2004 \\
\hline IAPV & $\begin{array}{l}\text { CCA TGC CTG GCG ATT CAC } \\
\text { CTG AAT AAT ACT GTG CGT ATC }\end{array}$ & 203 & 55 & de Miranda et al., In prep. \\
\hline ABPV & $\begin{array}{l}\text { CTC AAG TTA TAC GTA AAA TAG CTG GAA TT } \\
\text { AAC CAA CCT TGC TTC CCT TTA }\end{array}$ & 646 & 55 & Gauthier et al., 2007 \\
\hline CBPV & $\begin{array}{l}\text { TCA GAC ACC GAA TCT GAT TAT TG } \\
\text { TCT AAT CTT AGC ACG AAA GCC GAG }\end{array}$ & 1113 & 56 & Ribière et al., 2002; Blanchard et al., 2009 \\
\hline SBV & $\begin{array}{l}\text { GGA TGA AAG GAA ATT ACC AG } \\
\text { CCA CTA GGT GAT CCA CAC T }\end{array}$ & 426 & 48 & Tentcheva et al., 2004a \\
\hline VdMLV & $\begin{array}{l}\text { ATC CCT TTT CAG TTC GCT } \\
\text { AGA AGA GAC TTC AAG GAC }\end{array}$ & 438 & 50 & Gauthier et al., 2011 \\
\hline N. apis & $\begin{array}{l}\text { GAA CCA GGC GAT TTT GTT CCT A } \\
\text { CAC GCA TTG CTG CAT CAT TGAC }\end{array}$ & 250 & 56 & Chen et al., 2008; de Miranda et al., In preparation \\
\hline N. ceranae & $\begin{array}{l}\text { CGG ATA AAA GAG TCC GTT ACC } \\
\text { TGA GCA GGG TTC TAG GGAT }\end{array}$ & 250 & 50 & Chen et al., 2008 \\
\hline $\mathrm{EFB}$ & $\begin{array}{l}\text { CAG CTA GTC GGT TTG GTT CC } \\
\text { TTG GCTG TAG ATA GAA TTG ACA AT }\end{array}$ & 79 & 48 & Roetschi et al., 2008 \\
\hline AFB & GCA AGT CGA GCG GAC CTT GT & 237 & 50 & Bakonyi et al., 2003 \\
\hline
\end{tabular}

